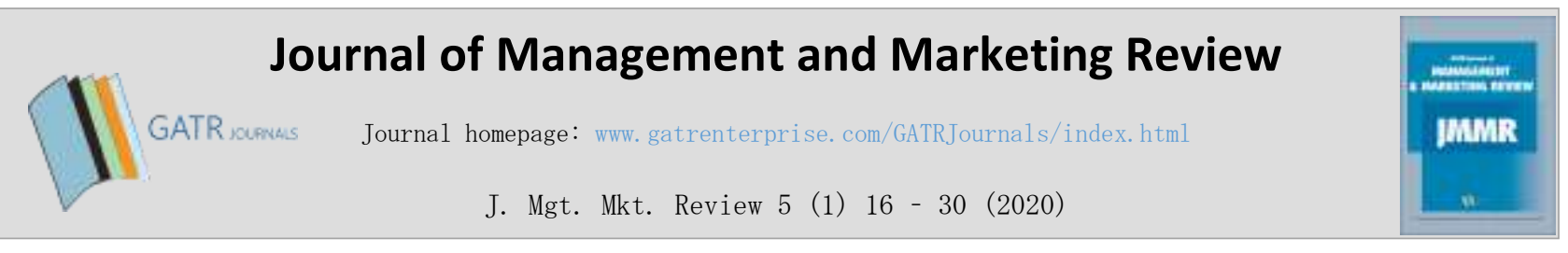

\title{
E-Service Quality and Price to Build Online Transportation Loyalty in Indonesia
}

\author{
Heny Hendrayati ${ }^{1}$, Askolani ${ }^{2}$, Mochamad Achyarsyah $^{3}$, Ceppy Trian Sudrajat $^{4}, \operatorname{Rahmy}$ \\ Karimah Syahidah ${ }^{5}$ \\ ${ }^{1,2,3,4}$ Universitas Pendidikan Indonesia, Jl. Dr. Setiabudhi No. 229, 40154, Bandung, Indonesia \\ ${ }^{5}$ Northwestern Polytechnical University, 127 Youyi W Rd, Beilin, Xi'an, Shaanxi, China
}

\begin{abstract}
Objective - The development of the online transportation industry has led to increasing competition. In Indonesia, Gojek and Grab are competitors in their industry. Each company strives to maintain the loyalty and satisfaction of its customers by setting up procedures such as e-service quality programs and pricing policies. Under these programs, consumers have different levels of satisfaction and loyalty for each type of online vehicle. This study aims to measure the influence of e-service quality and price to build loyalty through customer satisfaction Gojek and Grab.

Methodology/Technique - The type of the study is verification. An explanatory survey with simple random sampling technique is used. The sample includes 200 respondents from both online transportation operator's customers. The data of this study employs a path analysis with SPSS 25.0 and AMOS.

Findings - The results show that there is a positive influence between e-service quality and price to build loyalty through each Gojek and Grab customers' satisfaction. Thus, we can say that Gojek and Grab consumers are quite satisfied with the quality and price so they pay with loyalty.

Novelty - Good management in service companies will serve customers with great satisfaction, thus affirming the rightness of consumer loyalty to the company. Therefore, prices will be appropriate in addition to quality electronic services. This is because the relationship between the two can produce positive impacts such as consumer loyalty with mediation through satisfaction. Our study has several contributions, including adding insight into e-service studies, price, customers' satisfaction, and loyalty, especially in the online transportation industry.
\end{abstract}

Type of Paper: Empirical

Keywords: E-Service Quality, Price, Loyalty, Customer Satisfaction, Online Transportation.

Reference to this paper should be made as follows: Hendrayati; H, Askolani, Achyarsyah M, Sudrajat, C.T; Syahidah, R.K. (2020). E-Service Quality and Price to Build Online Transportation Loyalty in Indonesia, J. Mgt. Mkt. Review, 5(1) 16 - 30. https://doi.org/10.35609/jmmr.2020.5.1(2)

JEL Classification: M20, M21.

\section{Introduction}

Building customer loyalty is not easy. Identification of loyal feelings that needs to be developed in the minds of customers is an important management issue (Kim \& Jackson, 2009; Yoo \& Bai, 2012).

* Paper Info: Revised: January 11, 2019

Accepted: March 30, 2019

* Corresponding author: Heny Hendrayati

E-mail: henyhendrayati@upi.edu

Affiliation: Universitas Pendidikan Indonesia, Jl. Dr. Setiabudhi No. 229, 40154, Bandung, Indonesia 
Loyalty is not only about the level of customer loyalty to a brand (brand loyalty) but also covers service (service loyalty) (Asadpoor \& Abolfazli, 2017; Simões, Rita, \& Raposo, 2018). Without customer's loyalty, a company cannot develop properly. It can even experience a decline or a decrease in their business that threaten their existence. Therefore, most companies nowadays face the issue of attracting customers and maintaining their loyalty to survive and to develop (Khalifa \& Shen, 2005). Several studies have shown that loyalty is influenced by satisfaction (Asadpoor \& Abolfazli, 2017; Kao \& Lin, 2016; Yen \& Lu, 2008), customer perceived value and trust (Zehir \& Narcıkara, 2016), e-service quality (Carlson \& O'Cass, 2010; Chang, Lee, \& Lai, 2012) and prices (Subagio, 2016). Thus, it can be said that the perception of service quality has a positive effect on satisfaction (Sultan, 2012) and attractive price offers can create customer satisfaction and loyalty (Subagio, 2016).

Since the 1990s, loyalty has been studied in various marketing studies. In addition, since the 2000s, new loyalty programs have been developed in various industry sectors. This has come to the attention of company managers and academics in developing and researching loyalty programs (Cedrola, Memmo, \& Cedrola, 2010). Therefore, loyalty has been extensively examined in various sectors of the transportation industry. The public transport industry particularly needs researchers to investigate, especially in terms of honesty. Moreover, the Southeast Asian market has changed in terms of choice of public transportation facilities, including the development of online transportation providers (Septiani, Handayani, \& Azzahro, 2018). Competition involving online-based transportation providers in Indonesia is getting tougher after Uber was acquired by Grab in the Southeast Asia Region. The market share of online-based transportation in Indonesia is still controlled by Gojek (50.72\%). However, Grab has also experienced an increase in market share from $20.8 \%$ in 2016 to $49.8 \%$ in 2018 . This data shows how fast the movement and change in the number of customers from one brand to another and indicates the level of loyalty that still needs to be increased from this online-based transportation provider.

Loyalty can be discerned from positive responses and reviews from customers (Pandey, Tripathi, Jain, \& Roy, 2019). The more customers who respond to positive reviews on social media on a brand will provide the value of trust and increase the value of the company. However, problems will arise when the number of negative responses increases and this problem remains ignored. This may have a negative impact on the company itself, which will ultimately reduce the level of customer loyalty. Based on the results of a study on the sentiment of online transportation services by using the Naïve Bayes method to determine the prediction class, there were positive sentiments of $88.60 \%$ and negative sentiments of $11.40 \%$ with an accuracy of $86.80 \%$ (Pintoko \& L, 2018). That study indicates the relatively high level of negative sentiment. The level of satisfaction and loyalty that still needs to be improved in Indonesian online transportation services based on data collection from Twitter. Another indicator of loyalty is satisfaction with a product or service, that is so customer satisfaction is a measure of the extent to which the company managed to get their loyalty (Asadpoor \& Abolfazli, 2017).

People now are using mobile applications that provide a variety of services ranging from transportation, logistics, payment, food service services, and various other on-demand services. A great opportunity for businesses to use mobile apps to meet the needs of the community in the transportation sector, hence Gojek and Grab created mobile apps as tools and business tools to attract customers and service providers. The indicator of loyalty is the satisfaction of the product or service, while customer satisfaction is a measure of how much the company has attracted its customers. Based on data on the Google play store in 2019, it can be seen the number of satisfaction ratings for the Gojek and Grab applications that have been downloaded. That data shows that although many users are giving 5 stars, some users are giving 1 star to each application, in other words, many customers are still not satisfied with Gojek and Grab services. Therefore, the level of customer loyalty needs to be increased by Gojek and Grab.

Another sign that loyalty will be affected is the quality of electronic services (e-service). Gojek and Grab's competition will always focus on quality e-services to retain their customers. This is due to growing 
competition in transportation services, including application-based taxis (such as Gojek and Grab bikes) and web-based taxis, and businesses that continue to use self-service delivery services. When the value experienced by the customer is good for the quality of the electronic service received, it will create satisfaction for the customer using the e-services. In the context of achieving goals, service quality plays a very important role, including developing important factors in business competitiveness and success such as trust, increasing satisfaction, and fostering loyalty (Kao \& Lin, 2016). Therefore, in general, the literature indicates that the higher the quality of electronic services, the higher the satisfaction with electronic products (Al-dweeri et. al., 2019). This is in line with a previous study which indicates that e-service quality was found to be a core predictor of customer satisfaction and customer loyalty (Zhou et. al., 2018). Other effect that is currently happening is that competition through price wars is starting to tighten, which has allowed Gojek and Grab to compete to provide promotions that can persuade customers to use their services, so that customer satisfaction is rapidly changing.

According to previous research, price also plays a significant role in creating customer satisfaction and loyalty. Price is the amount of value charged for a product or the amount of value that customers exchange for the benefits of owning or using the product (Hamenda, 2018). Therefore, the price must be followed by services so that there is no imbalance between them. A large selection of products from Gojek and Grab with relatively competitive quality and prices will make it easy for customers to switch from one service provider to another. The issues related to loyalty must be addressed by Gojek and Grab. Gojek and Grab need to make efforts to maintain and increase the loyalty of their customers by providing high-quality services and setting appropriate prices to create satisfaction in the minds of customers which will have an impact on customer loyalty. These issues have led to fierce competition to influence its policies, which will have a positive impact on reducing the competitive loyalty of the Indonesian transport industry.

This paper will explain the effect of e-service quality and price on Gojek's and Grab's customers' satisfaction which will lead to their loyalty. Good management in service companies will serve customers with great satisfaction, thus affirming the rightness of consumer loyalty to the company. Therefore, we expect that prices will be appropriate in addition to quality electronic services. This is because we believe that the relationship between the two can produce positive impacts such as consumer loyalty with mediation through satisfaction. Our study has several contributions, including adding insight into e-service studies, price, customers' satisfaction, and loyalty, especially in the online transportation industry. A comparison of the two online transportation companies as a concrete example of a case to be subsequently corrected directly by the company concerned and/or used as an example for other companies, especially in the same industry.

The rest of this paper is organized as follows. The next part contains a review of the literature and the development of the study hypotheses. Section 3 describes the sample, research variables, and methodology. The results and discussion are reported in Section 4. Section 5 concludes this paper.

\section{Literature Review and Hypothesis Development}

\subsection{E-service Quality}

Service quality refers to the difference between the expectations and reality of consumers for the services they receive. Service quality can be determined by comparing customer perceptions of the service they receive with the actual service they expected. Service quality becomes the main thing that is considered seriously by the company which involves all of the company's resources. Service quality refers to customer evaluations about the core of the service, namely the company itself or the whole service organization. The quality of services in the online or electronic environment is one of the most important things in determining the success and failure of an electronic commerce activity. Services in the electronic environment (e-service) is one of the services using new media, such as websites.

Electronic service quality in its interaction with a website is one of the levels of effective and efficient website, which can facilitate users in electronic services, such as online shopping, searching, and finding 
information (Zehir \& Narckkara, 2016). According to some literature, perceived satisfaction and quality of service have a close relationship as previous researchers have said that the direct result of satisfaction is how customers perceived the quality (Asma, Dine, Wafaa, \& Redouan, 2018). Some studies have shown that eservice quality has a strong relationship with customer satisfaction (Hammoud, Bizri, \& El Baba, 2018; Asadpoor \& Abolfazli, 2017; Zehir \& Narckkara, 2016). In addition, electronic services have an impact on customer loyalty. As the research results show that service quality affects customer satisfaction as it can affect corporate loyalty (Asma, Dine, Wafaa, \& Redouan, 2018). Ahemed, Dowpiset and Chaipoopirutana (2018) conclude that customer satisfaction and customer loyalty are positively related. Thus, we can say that a significant predictor of customer satisfaction and customer loyalty is e-service quality. Based on the above, the following hypotheses are proposed:

H1: e-service quality has a positive relationship toward customer satisfaction.

H2: e-service quality has a positive relationship toward customer loyalty.

\subsection{Price}

Price is an important attribute in providing stimulating customer responses in choosing a product or service. According to Kotler and Armstrong (2016: 281), price is the amount of value charged for a product or the amount of value that customers exchange for the benefits of owning or using the product. While Tjiptono (2014: 39) argue that price is monetary units or other measures (including other goods and services) exchanged in order to obtain ownership or use rights of an item or service. Price has a direct effect on customer satisfaction (Cakrabuana \& Ali, 2019). Moreover, there are three indicators of building prices, including satisfaction. First is satisfaction with the total costs incurred, second is acceptability as the price offered is acceptable, and the third is reasonable as the price offered is reasonable (Weisstein et. al., 2017). In line with the previous study conducted by Yani, Wahyu and Usman (2019), prices significantly influence customer satisfaction. Good price conditions can increase customer satisfaction with online transportation services. That study also found that price has a significant and positive relationship with customer loyalty. Cited from the study case on Air Asia has explained that when the customers want to travel, they were influenced by low fares the most (Amiruddin, 2013). Based on the above, the following hypotheses are proposed:

H3: Price has a positive relationship toward customer satisfaction.

H4: Price has a positive relationship toward customer loyalty.

\subsection{Customer Satisfaction}

Customer satisfaction can be expressed as an evaluation, where perceptions toward the performance of alternative products or services selected can meet or exceed expectations before purchase. Customer satisfaction is a response to customer-presented behavior by comparing performance or observed results with expectations. If the result is lower than what the customers have expected, they will be disappointed or even dissatisfied. On the other hand, if the customers are satisfied based on expectations, and if the performance exceeds expectations, they will be satisfied. To measure perceptions of customer satisfaction, consumers can use metrics that are personal perceptions of a product or service by comparing the product or service with similar products/services from other companies (Bressolles et. al., 2014). Generating satisfaction through loyalty has been conceptualized as comprehensive satisfaction. Most previous studies have proven that customer loyalty is positively influenced by customer satisfaction. Hidayat, Saifullah and Ishak (2016) found that online customer satisfaction has a significant positive affect on online customer loyalty. This can also be 
interpreted that the higher level of customer satisfaction from Indonesian online customers is directly proportional to the level of online customer loyalty. Based on the above, the following hypothesis is proposed:

H5: Customer satisfaction has a positive relationship toward customer loyalty.

\subsection{Customer Loyalty}

According to Kotler and Armstrong (2016: 15), customer relationship management (CRM) is the most important concept in modern marketing. In a broader sense, CRM is the whole process of building and maintaining profitable customer relationships by delivering superior customer value and satisfaction. CRM is the integration of technology, people, and business processes to meet customer needs and to increase interaction with clients (Hendrayati \& Syahidah, 2018). Therefore, the focus of CRM is to improve the level of customer satisfaction, to increase customers' loyalty, and to boost revenue from existing customers in the face of high levels of competition, globalization, customer turnover, and the development of customer acquisition costs. The main goal of CRM strategies is to develop mutual relationships with customers (Shulka \& Pattnaik, 2018).

Customer loyalty is a person's behavior to repeat purchases. It is the relationship between the company and its customers through interpersonal communication and customer relationship management as it is a long-term asset. According to Shankar et. al (2019), customer loyalty is the level of customer loyalty in a brand or organization. It is a business conducted by each customer but often given the competitive environment that customers are less loyal to the brand or organization. An alternative perspective is to reverse the judgment and reflect on the level of loyalty a company makes to customers. If customers are satisfied with a company, they will become supporters and will help the company in expanding business opportunities from their friends and family. The company must strive to make the company's customers from suspect to advocates, thus it requires the company's efforts so that every customer feels satisfied every time they deal with the company, including interpersonal communication that is done in customer relationship management.

The concept of loyalty, which is part of the theory of customer relationship management, has been widely studied. Several studies have shown that loyalty is influenced by satisfaction (Asadpoor \& Abolfazli, 2017; Kao \& Lin, 2016; Yen \& Lu, 2008), customer perceived value and trust (Zehir \& Narcıkara, 2016), e-service quality (Carlson \& O 'Cass, 2010; Chang, Lee, \& Lai, 2012), and prices (Subagio, 2016). It can be concluded that the perception of service quality has a positive effect on satisfaction and attractive price offers can create customer satisfaction and loyal customers. Based on the above, the following hypothesis is proposed:

H6: E-service quality and Price have a positive relationship toward customer loyalty, mediated by customer satisfaction.

\section{Research Methodology}

\subsection{Data and Sample Selection}

This study is a descriptive and verification study. It employs descriptive survey and explanatory survey methods. The data collection was carried out on an object in the field by taking samples from a population using a questionnaire as a primary data collection tool that was processed to estimate the general opinion of the population of the object being studied. This research was conducted from May 2019 to July 2019. The object of the study is the online-based transportation providers, namely Gojek and Grab, as the pioneers of online transportation in Indonesia. It assessed the effect of e-service quality and price on customer loyalty through customer satisfaction. The customers consisted of university students. The reason is based on the 
results of research by Pratama and Wibawa (2018) which shows that the most use of online transportation based on demographics is 18-30 years old and most of the users work as students. This study uses a nonprobability sampling method. The total of population in Indonesia is 28,683 people. Therefore, 200 valid respondents are used as the sample. In addition, the questionnaires have been spread through both online and paper-based method in order to approach a more diversified group of website users. The questionnaire was distributed to the students who used the Gojek and/or Grab applications.

Primary data was obtained by the survey method. It was conducted by interviewing and distributing questionnaires to the respondents. The list of questions or questionnaires was made in a simple form with a closed question method given to respondents so that the data obtained is related to the purpose of this study. Respondents were asked to provide answers that correspond to responses the questions that reflect indicators of e-service quality, price, customer satisfaction, and loyalty. In order to analyze the data in this study, data testing was done using validity test, reliability test, and path analysis using SPSS 25.0 and AMOS.

\subsection{Description of the Variables}

In this study, we have two independent variables. They are e-service quality and price. To analyze the effect of the e-service variable, we adopted from a study conducted by Chang et. al. (2012) with a 7-point Likert scale. Four factors have been used to measure e-service quality variables, including efficiency, information quality, responsiveness, and privacy. Efficiency is the ability to meet needs without wasting energy and costs, information quality is when the information provided is appropriate, responsiveness refers to customer needs and complaints and privacy is used to measure the ability to maintain customer privacy. To analyze the effect of price as an independent variable, we adopted from a study conducted by Parasuraman et. al. (2005) and Weisstein et. al. (2017) with a 7-point Likert scale. Three factors have been used to measure price as an independent variable including satisfaction, acceptability, and reasonable. The dependent variable of this study is customer loyalty.

To analyze the dependent variable, we adopted from a study conducted by Pandey et. al. (2019) with a 7point Likert scale. Five factors have been used to measure customer loyalty, including share information, saying positive things, recommendations to friends, do more business and post positive messages. Sharing information is when customer share information about the company to others. Saying positive things is when customers say positive things about the company. Recommending friends is when customers recommend companies to their family and friends. Do more business refers to doing more business with the company. Post positive messages is when customers provide positive comments and reviews about the company. The other variable is customer satisfaction as a mediation variable. This study also has adopted from a study conducted by Pandey et. al. (2019) with a 7-point Likert scale. Four factors have been used to measure customer loyalty, including customer service, time, user friendly and standardization.

\subsection{Validity and Reliability}

The validity test shows the measurement ability of an indicator in measuring a concept. A validity test is carried out on each question item (indicator) that forms the research variable. To measure the validity in this study we used a Pearson correlation with the criteria if the significance of Pearson correlation values between each question with a total score is less than $\alpha=5 \%$, then the indicator is declared valid (Suharsimi Arikunto, 2013). 
Table 1. Validity Test

\begin{tabular}{|c|c|c|c|c|c|c|c|}
\hline Item & r-count & r-table & Validity & Item & r-count & r-table & Validity \\
\hline EF1 & 0.854 & 0.306 & Valid & TM2 & 0.783 & 0.306 & Valid \\
\hline EF2 & 0.821 & 0.306 & Valid & UF1 & 0.776 & 0.306 & Valid \\
\hline EF3 & 0.862 & 0.306 & Valid & UF2 & 0.793 & 0.306 & Valid \\
\hline EF4 & 0.57 & 0.306 & Valid & STD1 & 0.775 & 0.306 & Valid \\
\hline IQ1 & 0.907 & 0.306 & Valid & STD2 & $0.743^{*}$ & 0.306 & Valid \\
\hline IQ2 & 0.556 & 0.306 & Valid & $\mathrm{CS} 1$ & 0.731 & 0.306 & Valid \\
\hline IQ3 & 0.863 & 0.306 & Valid & $\mathrm{CS} 2$ & 0.718 & 0.306 & Valid \\
\hline IQ4 & 0.863 & 0.306 & Valid & TM1 & 0.587 & 0.306 & Valid \\
\hline RES1 & 0.52 & 0.306 & Valid & TM2 & 0.769 & 0.306 & Valid \\
\hline RES2 & 0.73 & 0.306 & Valid & UF1 & 0.728 & 0.306 & Valid \\
\hline RES3 & 0.732 & 0.306 & Valid & UF2 & 0.843 & 0.306 & Valid \\
\hline PR1 & 0.705 & 0.306 & Valid & STD1 & 0.72 & 0.306 & Valid \\
\hline PR2 & 0.812 & 0.306 & Valid & STD2 & 0.786 & 0.306 & Valid \\
\hline PR3 & 0.705 & 0.306 & Valid & SHA1 & 0.541 & 0.306 & Valid \\
\hline KEP1 & 0.812 & 0.306 & Valid & SHA2 & 0.806 & 0.306 & Valid \\
\hline KEP2 & 0.541 & 0.306 & Valid & SAY1 & 0.777 & 0.306 & Valid \\
\hline REA1 & 0.789 & 0.306 & Valid & SAY2 & 0.804 & 0.306 & Valid \\
\hline REA2 & 0.721 & 0.306 & Valid & REC1 & 0.559 & 0.306 & Valid \\
\hline ACC1 & 0.744 & 0.306 & Valid & REC2 & 0.728 & 0.306 & Valid \\
\hline $\mathrm{ACC} 2$ & 0.55 & 0.306 & Valid & DO1 & 0.545 & 0.306 & Valid \\
\hline $\mathrm{CS} 1$ & 0.739 & 0.306 & Valid & DO2 & 0.804 & 0.306 & Valid \\
\hline $\mathrm{CS} 2$ & 0.543 & 0.306 & Valid & POS1 & 0.657 & 0.306 & Valid \\
\hline TM1 & 0.687 & 0.306 & Valid & POS2 & 0.592 & 0.306 & Valid \\
\hline
\end{tabular}

Table 1 shows the validity test of e-service, price, satisfaction and loyalty. The results of the validity test show that all values of $\alpha(p<0.05)$, have a score of 0.000 . Thus, all of the variables are valid and no items need to be removed.

Reliability refers to an understanding that an instrument can be trusted enough to be used as a data collection tool because the instrument is already good (Suharsimi Arikunto, 2013). According to Sumadi Suryabrata (2004: 28), reliability shows the extent to which the results of measurements with these tools can be trusted. The measurement results must be reliable in the sense that they must have a level of consistency and stability. The results of the test are reliable if the scores obtained by participants are relatively the same despite repeated measurements. Reliability shows the extent to which the gauges are reliable. To measure reliability, the Cronbach alpha value is used. If the Cronbach alpha value is $>0.6$, then the question items that make up the research variable are said to be reliable.

Table 2. Reliability Test

\begin{tabular}{cccl}
\hline Variable & $\begin{array}{c}\text { Reliability } \\
\text { Coefficient }\end{array}$ & Score Limit & Reliability \\
\hline E-service quality & 0.956 & 0.600 & Reliable \\
Price & 0.942 & 0.600 & Reliable \\
satisfaction & 0.950 & 0.600 & Reliable \\
Loyality & 0.928 & 0.600 & Reliable \\
\hline
\end{tabular}


Table 2 shows the result of reliability test for e-service, price, satisfaction and loyalty. The results shows that all variables and instruments of this study are reliable. Thus, there no items need to be removed.

\subsection{Hypothesis Testing}

Hypothesis testing of this study was conducted to determine the influence of e-service quality and price on loyalty through satisfaction. Individual or partial testing for Gojek customers is done by t test, which is shown through path coefficients in Table 3.

Table 3. Path Coefficient of E-service and Price toward Satisfaction on Gojek's Consumers

\begin{tabular}{|c|c|c|c|c|c|c|}
\hline & \multirow[b]{2}{*}{ Model } & \multicolumn{2}{|c|}{ Unstandardized Coefficients } & \multirow{2}{*}{$\begin{array}{c}\begin{array}{c}\text { Standardized } \\
\text { Coefficients }\end{array} \\
\text { Beta }\end{array}$} & \multirow[b]{2}{*}{$\mathrm{t}$} & \multirow[b]{2}{*}{ Sig. } \\
\hline & & $\mathrm{B}$ & Std. Error & & & \\
\hline \multirow[t]{3}{*}{1} & (Constant) & 1,493 & 2,668 & & 0,560 & 0,576 \\
\hline & E-service quality & 0,326 & 0,039 & 0,512 & 8,450 & 0,000 \\
\hline & Price & 0,480 & 0,086 & 0,338 & 5,579 & 0,000 \\
\hline
\end{tabular}

Table 3 shows the t-value obtained by the e-service quality variable is 8.450 and the t-value of the variable price is 5.579. This value will be compared with the t-table value in the t-distribution table. With $\alpha=0.05$, and the t-table value of 1.652 was obtained. From the values above it can be seen that the calculated t-value of e-service quality and price variables are greater than t-table $=1.652$. Thus, it can be concluded that there is a significant relationship between e-service quality toward satisfaction as well as price toward satisfaction. Therefore, the first and third hypotheses are accepted.

Table 4. Path Coefficient of E-service and Price toward Satisfaction on Grab's Consumers

\begin{tabular}{|c|c|c|c|c|c|c|}
\hline \multirow{2}{*}{ Model } & \multicolumn{2}{|c|}{$\begin{array}{c}\text { Unstandardized } \\
\text { Coefficients }\end{array}$} & $\begin{array}{c}\text { Standardized } \\
\text { Coefficients }\end{array}$ & \multirow{2}{*}{ T } & \multirow{2}{*}{ Sig. } \\
\cline { 2 - 5 } & B & $\begin{array}{c}\text { Std. } \\
\text { Error }\end{array}$ & Beta & & \\
\hline 1 & (Constant) & 2,639 & 3,217 & & 0,820 & 0,413 \\
\cline { 2 - 5 } & $\begin{array}{c}\text { E-service } \\
\text { quality }\end{array}$ & 0,340 & 0,042 & 0,513 & 8,027 & 0,000 \\
\cline { 2 - 5 } & Price & 0,414 & 0,098 & 0,270 & 4,229 & 0,000 \\
\hline \multicolumn{7}{|c|}{ a. Dependent Variable: Satisfaction } \\
\hline
\end{tabular}

Table 4 shows that the t-value obtained by the e-service quality variable is 8.027 and the t-value of the price variable is 4.229 . This value will be compared with the $\mathrm{t}$ table value in the $\mathrm{t}$ distribution table. With $\alpha=$ 0.05 , and t-table value of 1.652 is obtained. From the values above it can be seen that the $t$-value obtained by the e-service quality and price variables is greater than t-table $=1.652$. Thus, it can be concluded that there is a significant relationship between e-service quality toward satisfaction as well as price on satisfaction. Therefore, the first and third hypotheses are accepted.

Table 5. Path Coefficient of E-service and Price toward Loyalty through Satisfaction on Grojek's Consumers

\begin{tabular}{|l|c|c|c|c|c|}
\hline \multirow{3}{*}{ Model } & \multicolumn{2}{|c|}{$\begin{array}{c}\text { Unstandardized } \\
\text { Coefficients }\end{array}$} & $\begin{array}{c}\text { Standardized } \\
\text { Coefficients }\end{array}$ & \multirow{2}{*}{ t } & Sig. \\
\cline { 2 - 4 } & B & $\begin{array}{c}\text { Std. } \\
\text { Error }\end{array}$ & Beta & \\
\hline
\end{tabular}


Heny Hendrayati, Askolani, Mochamad Achyarsyah, Ceppy Trian Sudrajat, Rahmy Karimah Syahidah

\begin{tabular}{|c|c|c|c|c|c|c|}
\multirow{4}{*}{1} & (Constant) & 5,889 & 2,552 & & 2,308 & 0,022 \\
\cline { 2 - 6 } & $\begin{array}{c}\text { E-service } \\
\text { quality }\end{array}$ & 0,275 & 0,043 & 0,389 & 6,396 & 0,000 \\
\cline { 2 - 7 } & Price & 0,327 & 0,088 & 0,207 & 3,697 & 0,000 \\
\cline { 2 - 7 } & Satisfaction & 0,378 & 0,068 & 0,341 & 5,558 & 0,000 \\
\hline
\end{tabular}

Table 5 shows that the coefficient used is the beta coefficient of the standard coefficient. The first beta coefficient is 0.389 , partially e-service quality variables obtained the value of t-count $=6.396$ greater t-table $=1.652$ with a significant value 0.000 . The significant value of 0,000 is smaller than the probability value of 0.05 . This result shows that e-service quality has a positive and significant effect on Gojek customer loyalty. Therefore, the second hypothesis is accepted. The second beta coefficient is 0.207 , partially the price variable obtained the value of $t$ arithmetic $=3.697$ is greater than $t$ table $=1.65$ with the significant value 0.000 . The significant value of 0.000 is smaller than the probability value of 0.05 or the value of $0.000<0.05$. This result shows that price has a positive and significant effect on Gojek customer loyalty. Therefore, the fourth hypothesis is accepted. The third beta coefficient is 0.341 , partially the satisfaction variable obtains the value of $\mathrm{t}$-arithmetic $=5.558$ greater than $\mathrm{t}$-table $=1.65$ with the significant value of 0.000 . The significant value of 0.000 is smaller than the probability value of 0.05 or the value of $0.000<0.05$. This result shows that satisfaction has a positive and significant effect on Gojek customer loyalty. Therefore, the fifth hypothesis is accepted.

Individual or partial testing for Grab customers is done by t-test, which is shown through path coefficients in Table 6.

Table 6. Path Coefficient of E-service and Price toward Loyalty through Satisfaction on Grojek's Consumers

\begin{tabular}{|c|c|c|c|c|c|c|}
\hline \multirow{2}{*}{ Model } & \multicolumn{2}{|c|}{$\begin{array}{c}\text { Unstandardized } \\
\text { Coefficients }\end{array}$} & $\begin{array}{c}\text { Standardized } \\
\text { Coefficients }\end{array}$ & \multirow{2}{*}{ t } & \multirow{2}{*}{ Sig. } \\
\cline { 3 - 5 } & B & Std. Error & Beta & & \\
\hline \multirow{4}{*}{1} & (Constant) & 6,287 & 2,972 & & 2,116 & 0,036 \\
\cline { 2 - 5 } & $\begin{array}{c}\text { E-service } \\
\text { quality }\end{array}$ & 0,232 & 0,045 & 0,320 & 5,154 & 0,000 \\
\cline { 2 - 5 } & Price & 0,402 & 0,094 & 0,240 & 4,266 & 0,000 \\
\cline { 2 - 5 } & Satisfaction & 0,400 & 0,066 & 0,366 & 6,090 & 0,000 \\
\hline
\end{tabular}

Table 6 shows that the coefficient used is the beta coefficient of the standard coefficient. The first beta coefficient of 0.320 , partially e-service quality variables obtained the value of $\mathrm{t}$-count $=5.514$ greater t-table $=1.652$ with a significant value of 0.000 . Hence, it can be concluded that the significant value of 0.000 is smaller than the probability value of 0.05 . This result shows that e-service quality has a positive and significant effect on Grab's customer loyalty. Therefore, the second hypothesis is accepted. The second beta coefficient is 0.240 , partially the price variable obtains the value of $\mathrm{t}$-count $=4.266$ greater than $\mathrm{t}$-table $=1.65$ with the significant value of 0.000 . The significant value of 0.000 is smaller than the probability value of 0.05 or the value of $0.000<0.05$. This result shows that price has a positive and significant effect on Grab's customer loyalty. Therefore, the fourth hypothesis is accepted. The third beta coefficient 0.366 , partially satisfaction variable obtained the value of $t$-count $=6.090$ is greater than $t$-table $=1.65$ with a value of Sig 0.000 . The significant value of 0.000 is smaller than the probability value of 0.05 or the value of $0.000<0.05$. This result shows that satisfaction has a positive and significant effect on Grab's customer loyalty. Therefore, the fifth hypothesis is accepted.

Determination analysis is used to explain how much influence e-service quality, price, and satisfaction have on the loyalty of Gojek customers. The results of data processing showed the coefficient of determination (R Square) of 0.714 or $71.4 \%$. The framework of the empirical causal influence between e- 
service quality, price, and satisfaction have on the loyalty of Gojek customers can be made through the structural equation as follows:

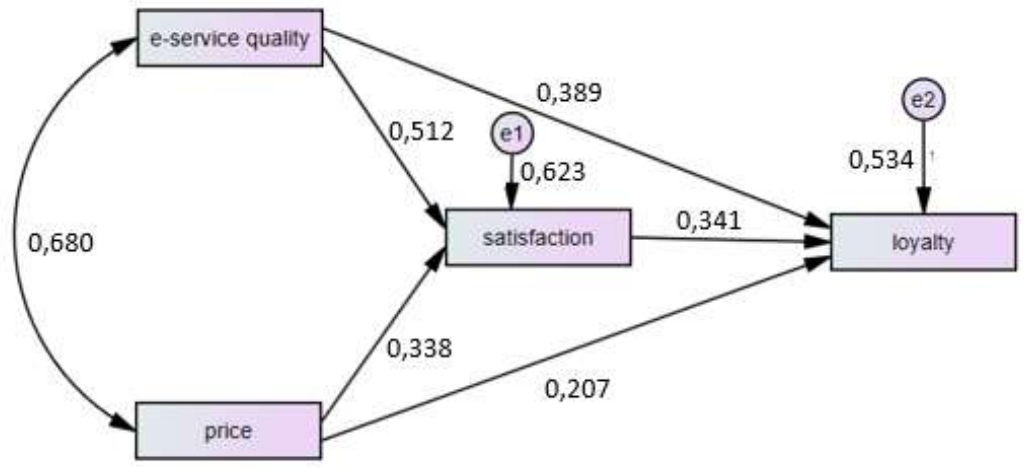

Figure 1. Causality E-service quality, Price, and Satisfaction on The Loyalty of Gojek Customers

The calculation results of the substructure 2 path analysis show that the information can be concluded objectively. The first is the contribution of the effectiveness of e-service quality that directly affects loyalty is 0.389 . Second, the contribution of price that directly affects loyalty is 0.341 . Third, the contribution of the level of satisfaction that directly affects the level of loyalty is 0.207 . Fourth, the contribution of the effectiveness of e-service quality and price and satisfaction effect on loyalty is 0.714 . These results have obtained a picture of the effect of e-service quality and price on loyalty through Gojek customer satisfaction. Therefore, the sixth hypothesis is accepted.

The determination analysis is used to explain how much influence e-service quality, price, and satisfaction has on Grab's customer loyalty. The results of data processing show the coefficient of determination ( $R$ Square) of 0.653 or $65.3 \%$. The framework of the empirical causal influence between e-service quality, price, and satisfaction have on the loyalty of Grab customers can be made through the structural equation as follows:

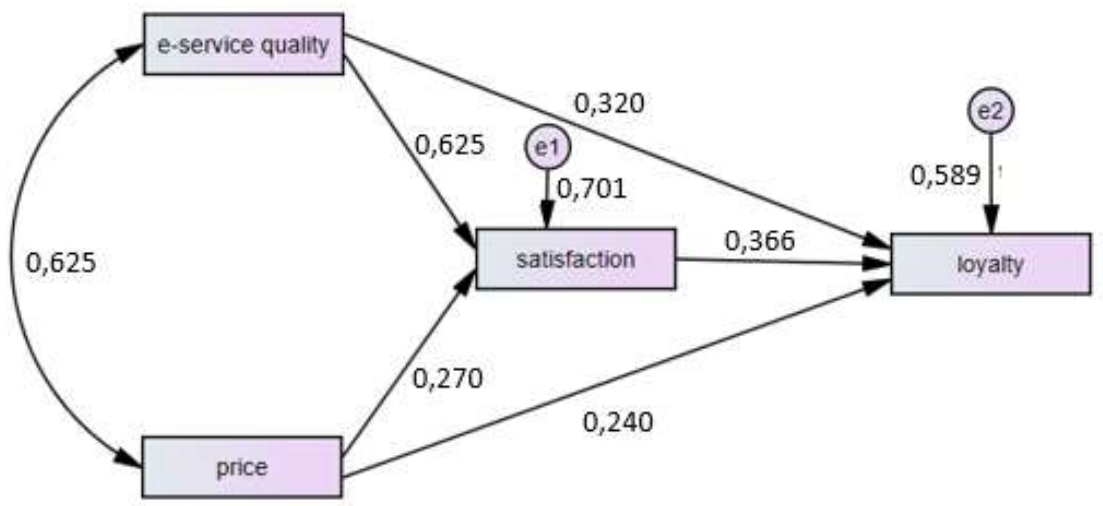

Figure 2. Causality E-service quality, Price, and Satisfaction on The Loyalty of Grab Customers

The calculation results of the substructure 2 path analysis show that the information can be concluded objectively. First, the contribution of the effectiveness of e-service quality that directly affects loyalty is 0.320. Second, the contribution of price-effectiveness that directly affects loyalty is 0.240 . Third, the 
contribution of the level of satisfaction that directly affects the level of loyalty is 0.366 . Fourth, the contribution of the effectiveness of e-service quality and price and satisfaction affect loyalty is 0.653 . These results have obtained a picture of the effect of e-service quality, price on loyalty through Grab customer satisfaction. Therefore, the sixth hypothesis is accepted.

\section{Results and Discussion}

\subsection{Effect of E-service quality on Gojek's and Grab's Customer Satisfaction}

The results of data processing for Gojek customers and the statistical tests found that there is a positive influence of e-service quality on satisfaction. This shows the better performance of e-service quality will have a positive impact on customer satisfaction. The application of online service programs is mainly related to the level of ease and practicality of using the Gojek application. The same thing was also found in Grab customers. Grab must maintain the concept more easily and practically in maintaining customer satisfaction. This is in line with previous studies, that customers will be more satisfied if the application is relatively easy, convenient, and efficient in getting products or services (Parasuraman et. al., 2005). The quality of services in the online or electronic environment is one of the most important things that determines the success and failure of electronic commerce activity. Services, in the electronic environment (e-service), is one of the services using new media, namely website. Electronic service quality in its interaction with a website is one of the levels of effective and efficient websites, which can facilitate users in electronic services, such as online shopping, searching, and finding information (Zehir \& Narckkara, 2016).

E-service quality on the Gojek application achieves good ratings from customers, as well as the Grab application. Based on this research, we found that Gojek consumers found the Gojek app easy to use by anyone so that it really helped Gojek customers meet their needs. In addition, consumers revealed that Gojek was still low in the speed of responding to complaints from customers. Whereas in the Grab application, we found that Grab consumers showed a high level of trust in the application they used, this was related to the ease of doing transactions. However, consumers also believe that Grab needs more time to respond to customer complaints.

\subsection{Effect of Price on Gojek's and Grab's Customer Satisfaction}

The results of data processing and Gojek customer statistical tests show that price has a positive effect on customer satisfaction. This means a positive valuation of the price on the Gojek application can increase Gojek's customer satisfaction. The same conclusion was made in relation to Grab customers. Based on the results of data processing and statistical tests, price has a positive effect on Grab's customer satisfaction. The price referred to in this study is not just a nominal price but rather tends to be directed at elements of marketing programs such as product selling prices, discounts, and payment systems that are applied to product users. For customers, price is important because it can give them profit from the market. This study is also in the position that price can have an impact on satisfaction. It reinforces the opinion that competition makes the business world try to satisfy customer needs at low prices. This proves that the price variable has a positive influence on customer satisfaction (Subagio, 2016).

The price variable on the Gojek application also achieves a good rating from customers, this is based on customer satisfaction with the promotion given. From this data, it can be seen that the average Gojek customer rates the promotion to be very positive, while the price offered by Gojek still assesses that it is too expensive when compared to Grab. This is because Gojek still uses high tariff limits compared to Grab which can be cheaper. While consumer ratings for Grab applications, many customers are still tempted by promotions given by Grab, related to the price offered can be accepted but due to the Grab tariff increase policy, as well as penalties for customers who cancel orders in the form of additional delivery rates at Grab 
are still being considered for consumers. Thus, this can indicate that the price policy is one indicator of customers choosing a service.

\subsection{Effect of e-service quality on Gojek's and Grab's Customer Loyalty}

The results of data processing and Gojek customer statistical tests showed that e-service quality had a positive effect on customer loyalty. This means an increase in e-service quality on Gojek's application can increase Gojek's customer loyalty. Gojek must continue to innovate to improve the quality of service programs that are already varied, optimizing good services such as Go-Ride and Go-Food, and providing more information and promotions related to other service programs. The same conclusion was also made in relation to Grab's customers. The results of data processing and statistical tests identified a positive relationship between e-service quality and loyalty. Grab must continue to improve its service program to maintain customer loyalty. Grab service programs can be reproduced and modified. Therefore, customers can have more alternatives to using Grab's services. This study is in the position that increasing the e-service quality program can increase Gojek's and Grab's customer loyalty. This reinforces the opinion that e-service quality has a positive impact on loyalty (Carrasco, Sánchez-Fernández, Muñoz-Leiva, Francisca Blasco, \& Herrera-Viedma, 2017; Gazor, Mirashrafi, \& Ameleh, 2012; EY Kim \& Jackson, 2009).

\subsection{Effect of Price on Gojek's and Grab's Customer Loyalty}

The results of data processing and customer statistical tests show that price has a positive effect on Gojek's customer loyalty. This means that a positive valuation of the price on Gojek's application can increase Gojek's customer loyalty. The same conclusion was made in relation to Grab's customers. Based on the results of data processing and statistical tests, price has a positive effect on customer loyalty. This shows that the price policy is an indicator of choosing a service. This study is in the position that price has a positive impact on satisfaction, it reinforces the opinion that an attractive price quote can create customer satisfaction and loyal customers (Subagio, 2016).

\subsection{Effects of Satisfaction on Gojek's and Grab's Customer Loyalty}

The results of data processing and customer statistical tests show that customer satisfaction has a positive effect on Gojek's customer loyalty. This means that a positive assessment of satisfaction with Gojek's application can increase Gojek's customer loyalty. The same conclusion was made in relation to Grab. Based on the results of data processing and statistical tests, customer satisfaction has a positive effect on Grab's customer loyalty. If customers are satisfied, this can increase the intensity of buying from them (Assael, 1995). The creation of an optimal level of customer satisfaction encourages the creation of loyalty in the minds of satisfied customers earlier. Customer loyalty is seen as the strength of the relationship between a person's relative attitude and business. This relationship is seen because it is bridged by social norms and situational factors. The results also show that although the effect of customer satisfaction on customer loyalty is positive, the effect of customer satisfaction with loyalty is not linear. This is reinforced by a study that the relationship between satisfaction and loyalty is unclear (Jennifer, 2000). It is also supported by the previous study which has found that some customers who expressed customer satisfaction were still switching to other brands while some dissatisfied customers do not switch brands (Jennifer, 2000).

The satisfaction variable on the Gojek application achieves good ratings from consumers. This is because consumers get satisfaction in using the application easily, but they feel unsatisfied with customer service in receiving complaints. In addition, Grab consumers also believe that the Grab deserves a good rating for satisfaction. This is due to customer satisfaction with the application service as promised, Grab is able to increased consumer confidence due to the delivery feature that requires drivers to photograph the goods and the person responsible for the goods on the Grab express and GrabFood service features. However, 
satisfaction with customer service in receiving complaints is also not fully met. This is because Grab needed time to decide whether the complaint was related to the driver, application or Grab partner, so it took a long time. Thus, we argue that although the results of the effect of satisfaction on customer loyalty are positive, the effect of satisfaction with loyalty is not linear, meaning that even if customers are satisfied, this does not rule out the possibility that they will switch brands.

\subsection{Effect of E-service quality and Price on Loyalty based on Gojek's and Grab's Customer Satisfaction}

The results of data processing and statistical tests show that e-service quality and price have a positive effect on Gojek's customer loyalty through customer satisfaction. The same conclusion was made in relation to Grab's customers. Based on the results of data processing and statistical tests, e-service quality and price have a positive effect on loyalty through customer satisfaction. This study is in the position that e-service quality and price have a positive effect on loyalty through customer satisfaction. This means that if the simultaneous assessment of e-service quality and price is good, it will also have a positive impact on loyalty through variable satisfaction. This reinforces previous studies that e-service quality can affect customer loyalty through satisfaction (Zehir \& Narcikara, 2016) and price influences loyalty through satisfaction (Subagio, 2016).

\section{Conclusions}

Based on the results of this study, it can be concluded that e-service quality and price have a significant effect on customer loyalty through satisfaction. Thus, we can say that Gojek and Grab consumers are quite satisfied with the quality and price so they pay with loyalty. Nevertheless, there are still some important points that need to be improved by Gojek and Grab such as e-service quality, price or promotion rates. This is because there are still many Gojek and Grab customers who still feel unsatisfied with complaints and slow responses. Therefore, to overcome this, both Gojek and Grab can open other complaint handling lines that can be accessed more quickly, for example, live chat features or telephone lines that can be accessed 24 hours by customers. Further, Gojek and Grab in assessing customer loyalty must be able to make some improvement, particularly on the frequency indicator to try other types of services in the application in building business. To overcome this, Gojek and Grab must be willing to take advantage of advertising channels on television and social media relating to the services owned by Gojek. Gojek and Grab are also expected to be able to build relationships with other industries through sponsorships and other similar forms so that customers can get to know more about the services available on the Gojek application.

This study has several limitations. First, the respondents in this study only focus on university students and the minimum number is 200 respondents. This may not be representative of Indonesian public online transportation customers. Therefore, further research is expected to improve the quality of respondents both in number and profession. Second, the study only focuses on service and price variables, while many other factors might affect customer satisfaction to increase their loyalty. Therefore, further research is expected to consider other factors to test customer satisfaction and loyalty factors. Lastly, the research model in this study is suggested to be modified and/or developed to become a better research construct model.

\section{Acknowledgements}

We would like to express our deepest gratitude to School of Postgraduate - Universitas Pendidikan Indonesia and Management Study Program - Faculty of Economics and Business of Education - Universitas Pendidikan Indonesia, who have facilitated and helped the research from the beginning until its completion. 


\section{References}

Ahemed, N., Dowpiset, K., \& Chaipoopirutana, S. (2018). Measurement and Evaluation of E-service Quality Dimension on Customer Satisfaction and Brand Loyalty towards Online Travel Agency. Journal of Economics and Management Strategy, 4 (2) , 1-16. Http://158.108.80.26/kuojs-3.0.2/index.php/jems/article/view/1062

Asadpoor, S., \& Abolfazli, A. (2017). Effect of Electronic Service Quality on Customer Satisfaction and Loyalty Saderat Bank ${ }^{\text {ee }} \mathrm{S}$ Customers ${ }^{\text {ee }}$. International Journal of Scientific Study, 5(4), 407-411. https://doi.org/10.17354/ijssI/2017/56

Asma, S., Dine, M. S. B., Wafaa, B., \& Redouan, A. (2018). The effect of perception quality/price of service on satisfaction and loyalty Algerians customers evidence study Turkish Airlines. Int J Econ Manag Sci, 7(503), 2. https://doi.org/10.4172/2162-6359.1000503

Cakrabuana, A., \& Ali, M. M. (2019). Analysis of Effects of Price, Service Quality, and Information Factors on Customer Satisfaction and Its Impact on the Commitment of Broadband Internet Customers.https://doi.org/10.7176/EJBM

Carlson, J., \& O'Cass, A. (2010). Exploring the relationships between e-service quality, satisfaction, attitudes and behaviours in content-driven e-service web sites. Journal of services marketing. https://doi.org/10.1108/08876041011031091

Carrasco, R. A., Sánchez-Fernández, J., Muñoz-Leiva, F., Blasco, M. F., \& Herrera-Viedma, E. (2017). Evaluation of the hotels e-services quality under the user's experience. Soft Computing, 21(4), 995-1011. https://doi.org/10.1007/s00500-015-1832-0

Chang, H. H., Lee, C. H., \& Lai, C. Y. (2012). E-Service quality and relationship quality on dealer satisfaction: Channel power as a moderator. Total Quality Management \& Business Excellence, 23(7-8), 855-873. https://doi.org/10.1080/14783363.2011.637792

Nemati, B., Gazor, H., Mir Ashrafi, S., \& Ameleh, K. (2002). Analyzing e-service quality in service-based website by E-SERVQUAL. Management Science Letters, 2(2), 727-734. https://doi.org/10.5267/j.msl.2011.12.002

Hammoud, J., Bizri, R. M., \& El Baba, I. (2018). The impact of e-banking service quality on customer satisfaction: Evidence from the Lebanese banking sector. SAGE Open, 8(3), 2158244018790633. https://doi.org/10.1177/2158244018790633

Hendrayati, H., \& Syahidah, R. K. (2018). Barriers and Possibilities of Implementation of Customer Relationship Management on Small and Medium Enterprises by Womenpreneurs. Jurnal Bisnis dan Manajemen, 19(2), $72-87$. http://dx.doi.org/10.24198/jbm.v19i2.196

Hidayat, A., Saifullah, M., \& Ishak, A. (2016). Determinants of satisfaction, trust, and loyalty of Indonesian ecommerce customer. International Journal of Economics and Management, 10(1), 151-166. http://www.ijem.upm.edu.my/vol10noS/11)-

VOL_10(S)2016_Anas\%20Hidayat(Determinants\%20of\%20Satisfaction...)Pages\%20151-166.pdf

Jennifer, R., \& Jillian, D. (2000). Disloyalty: a closer look at non-loyals. Journal of Consumer Marketing, 17(6), 538547.https://doi.org/10.1108/07363760010349948

Kao, T. W. D., \& Lin, W. T. (2016). The relationship between perceived e-service quality and brand equity: A simultaneous equations system approach. Computers in Human Behavior, 57, 208218.https://doi.org/10.1016/j.chb.2015.12.006

Khalifa, M., \& Shen, N. (2005, January). Effects of electronic customer relationship management on customer satisfaction: A temporal model. In Proceedings of the 38th Annual Hawaii international conference on system sciences (pp. 171a-171a). IEEE. https://doi.org/10.1109/HICSS.2005.224

Kim, E. Y., \& Jackson, V. P. (2009). The effect of E-SERVQUAL on e-loyalty for apparel online shopping. Journal of Global Academy of Marketing, 19(4), 57-65. https://doi.org/10.1080/12297119.2009.9707305

Kim, M. G., Yang, H., \& Mattila, A. S. (2018). The Impact of Customer Loyalty and Restaurant Sanitation Grades on Revisit Intention and the Importance of Narrative Information: The Case of New York Restaurant Sanitation Grading System. Cornell Hospitality Quarterly, 59(3), 275-284. https://doi.org/10.1177/1938965517744075

Parasuraman, A., Zeithaml, V. A., \& Malhotra, A. (2005). ES-QUAL: A multiple-item scale for assessing electronic service quality. Journal of service research, 7(3), 213-233.https://doi.org/10.1177/1094670504271156

Pintoko, B. M., \& Lhaksmana, K. M. (2018). Sentiment Analysis of Online Transportation Services on Twitter Using the Naïve Bayes Classifier Method. eProceedings of Engineering, 5 (3). https://libraryeproceeding.telkomuniversity.ac.id/index.php/engineering/article/view/7447 
Shukla, M. K., \& Pattnaik, P. N. (2019). Managing customer relations in a modern business environment: Towards an ecosystem-based sustainable CRM model. Journal of Relationship Marketing, 18(1), 17-33. https://doi.org/10.1080/15332667.2018.1534057

UTOMO, H. S., \& SUKRESNA, I. (2019). Study of Interest in Reusing Xiaomi Brand Smartphone Products at the Mi Fans Community in Central Java (Doctoral dissertation, Faculty of Economics \& Business). https://doi.org/10.1016/j.jretconser.2018.03.011

Dimyati, M., \& Subagio, N. A. (2016). Impact of service quality, price, and brand on loyalty with the mediation of customer satisfaction on Pos Ekspres in East Java. Mediterranean Journal of Social Sciences, 7(4), 74. https://doi.org/10.5901/mjss.2016.v7n4p

Sultan, M. A. (2012). The Process of Forming Tourist Behavior of Tourist Returns. Business Strategy, 16 (1), $107-118$. Yen, C. H., \& Lu, H. P. (2008). Effects of e-service quality on loyalty intention: an empirical study in online auction. Managing Service Quality: An International Journal.

https://www.emerald.com/insight/content/doi/10.1108/09604520810859193/full/html http://dx.doi.org/10.2139/ssrn.3311311

Yoo, M., \& Bai, B. (2013). Customer loyalty marketing research: A comparative approach between hospitality and business journals. International Journal of Hospitality Management, 33, 166-177. Yoo, M., \& Bai, B. (2013). Customer loyalty marketing research: A comparative approach between hospitality and business journals. International Journal of Hospitality Management, 33, 166-177. 